\title{
太陽熱利用のための薄膜生成とそのふく射特性
}

\section{Thermal Radiative Properties of a Thin Film for Solar Thermal Energy Use}

\author{
○正 宮崎 康次（九州工大）正 矢吹 智英（九州工大） \\ 学 今泉 凌佑（九州工大）宮越 哲哉（九州工大）
}

Koji Miyazaki ${ }^{1}$ Tomohide Yabuki ${ }^{1}$ Ryosuke Imaizumi ${ }^{1}$ and Tetsuya Miyagoshi ${ }^{1}$

${ }^{1}$ Kyushu Institute of Technology, 1-1 Sensui-cho, Tobata-ku, Kitakyushu 804-8550, Japan

Key Words: Thermal Radiation, Solar Thermal, Thin Film

\section{1. はじめに}

波長選択的なふく射特性として, 波長 $2 \mu \mathrm{m}$ を境として可視光を強く吸収し, 赤外光を強く反射する特性を生み出すと 太陽光によって加熱された自身の熱を赤外線放射によって失うことなく有効に加熱される特性の高い太陽熱吸収膜を生 成できる(1). 光の波長よりも短い金属ナノ粒子を酸化物内で分散させて (サーメット), 見かけの誘電率を制御し, 太陽熱 利用に活か寸サーメッ卜膜の最適設計も報告されている(2). 本研究では, 金属ナ/粒子を酸化物原料となる溶液に混合し て薄膜生成し，その熱ふく射特性を測定することでサーメット作製手法の有用性についても議論した.

\section{2. 実験方法}

$\mathrm{W}$ ナノ粒子もしくは $\mathrm{Ag}$ ナノ粒子を $\mathrm{SiO}_{2}$ 原料溶液に混合し, 金属ナノ粒子を含む $\mathrm{SiO}_{2}$ 薄膜を生成した. $\mathrm{SiO}_{2}$ 薄膜生成 には, 原料となる溶液を塗布し加熱処理して目的の薄膜を生成する MOD 法を用いた. 基板には反射膜として Ag 薄膜 を生成したガラス基板を用いた. W ナノ粒子を長期間保管していると, 凝集して粒子直径がマイクロサイズにまで成長し てしまうため, 超音波ホモジナイザーを照射してから用いた. 得られた薄膜のふく射スペクトルを放物面鏡を組み合わせ た分光計で測定した.

\section{3. 実験結果}

作製した W サーメット, $\mathrm{Ag}$ サーメットのふく射吸収スペクトルを 図 1 に示寸. 波長 $1.1 \mu \mathrm{m}$ から $2.0 \mu \mathrm{m}$ は空気中の水分などに よる吸収も大きく, 定量的測定が難しかった. W ナノ粒子を体 積分率 30\%, Ag ナノ粒子を体積分率 40\%で含むよう原料濃 度調整して生成した薄膜のふく射特性と数值計算結果を合わ せてプロットしている. いずれもサーメット 1 層膜であるため, 極 端な太陽熱吸収膜とはなっていないものの, 可視光域で吸収率 0.9 で, 徐々に吸収率が低下寸る膜となっていることが確認でき た. ただし SEMにより薄膜を観察したところ, 金属ナノ粒子分散 なども設計通りになっておらず, 今後の課題である.

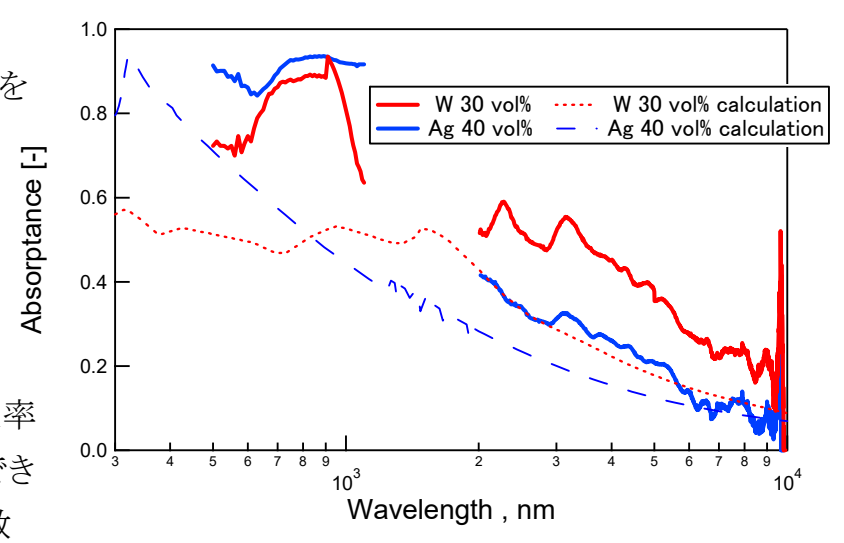

図 1 生成したサーメット膜のふく射スペクトル

\section{4. おわりに}

蒸着を使わないサーメット膜の生成として，金属ナノ粒子を酸化物薄膜原料に混合させて，塗布によって薄膜 を生成する手法を提案した. 生成したサーメッ膜のふく射特性を測定したところ, 可視光領域で高い吸収率を示し, 長 波長側で徐々に吸収率が小さくなる膜を生成することができた. 今後は, さらに特性の高い 2 層サーメッ薄膜の作成の ため, 金属ナノ粒子生成の確立と膜内での均一な混合, 膜の薄膜化などが課題である.

\section{参考文献}

(1) Zhang, Q. and Mills, D. R., Appl. Phys. Lett., 60 (1992), 545.

(2) Sakurai, A. et al., JQRST, 132 (2014), 80. 